\title{
Effect of soil erosion and topography on distribution of cadmium (Cd) in Sumani watershed, west Sumatra, Indonesia
}

\author{
Aflizar $^{1, *}$, Aprisal $^{3}$, Cornelius Idowu Alarima ${ }^{2,4}$, and Tsugiyuki Masunaga ${ }^{4}$ \\ ${ }^{1}$ State Polytechnic Payakumbuh for Agriculture, 26271, West Sumatra, Indonesia \\ ${ }^{2}$ Federal University of Agriculture, Abeokuta Nigeria \\ ${ }^{3}$ Soil Science Department of Agriculture Faculty of Andalas University, Indonesia \\ ${ }^{4}$ Faculty of Life and Environmental Science, Shimane University, 1060 Nishikawatsu, Matsue, Shimane 6908504, Japan
}

\begin{abstract}
The purpose of this study was to characterize and present the distribution of heavy metals especially $\mathrm{Cd}$ on agricultural and non-agricultural lands and river sediments in relation to soil erosion and topography status in watersheds. The study was conducted for a detailed soil survey by collecting 146 soil sample based on land use, soil family and topography position and 23 river sediments sample. The Cd was extracted by $0.1 \mathrm{M} \mathrm{HCl}$ and determined by ICP. The result showed that the concentration of $\mathrm{Cd}$ in soil and river sediment were low in toxicity based on FAO recommendation $(\mathrm{Cd} 0.4 \mathrm{mg} / \mathrm{kg}$ ) with only 4 out of 169 sampling sites contained Cd exceeding the toxicity level. Volcanic ash from Mount Talang Volcano is a natural source of $\mathrm{Cd}$ in Sumani watershed. Cd concentration was low in areas with high soil erosion, which indicate material translocation caused by high soil erosion that accumulates sediment in plains and rivers. Agricultural soil was found to be low in soil $\mathrm{pH}$ and clay accompanied by high $\mathrm{R}$ factor and upland topography hence the increase in $\mathrm{Cd}$ concentration of the soil. The study concluded that $\mathrm{Cd}$ abundance in soils may be influenced by soil $\mathrm{pH}$, texture, total carbon, erosion factors, and topography.
\end{abstract}

\section{Introduction}

Sumani Watershed landscaped has been subjected to intensive agricultural practices in West Sumatra province and under intensive chemical fertilizers and pesticides use since introduction of Green Revolution in 1974 in Indonesia. Sumani watershed as shown in Fig 1, is used for rice production $(24 \%)$, vegetable garden $(25 \%)$, mixed garden (14\%), settlement (12\%), coconut production $(2 \%)$, slash and burn bush $(6 \%)$, tea plantation $(0.1 \%)$ and forest reserve $(16 \%)[1,3]$.

Farmers generally provide Urea, $\mathrm{KCl}$, and SP-36 for vegetable gardens, mixed gardens and rice production with the aim of increasing soil nutrients to increase agricultural production. Due to population growth in watersheds, there has been an expansion of agricultural land by cutting down the forest for new agricultural land. Therefore, the watershed is under an accelerated erosion [2] reported that soil erosion results in agricultural land prone to serious environmental problems and loss of agricultural production. Therefore, understanding the erosion process is very important to ensure food security. Indonesia as a tropical region with high rainfall throughout the year. Soil erosion in Indonesia is one of the most serious sources of environmental degradation problem with call for special attention [4].
Java Island soil was formed from volcanic soils and was reported in 1989 to have an average erosion of 6-12 $\mathrm{Mg} / \mathrm{ha} / \mathrm{y}$ resulting in economic loss of US \$ 340-406 million. Farmers in this region suffered eighty percent of the loss as a result of the decline in agricultural productivity [5]. To measure soil erosion on a watershed where there are methodological limitations, estimation based on a model approach tailored to the research objectives should be adopted for accurately measuring erosion on small plot experiments [6]. Universal soil loss equation, USLE [7], which requires only few and tested input parameters can be used as a tool to make land and water conservation plans which have been used throughout Indonesia with little adjustment in factor values in relation to case at hand $[1,2,8]$.

In determining soil erosion models, USLE was used to estimate the level of soil erosion on the plot scale but however, expanded to the watershed scale by integrating USLE with Surfer or GIS tool. Erosion rate estimated by USLE, proved to be more reliable than that measured at the watershed outlet [9]. This can however be improved using Sediment Delivery Ratio (SDR). SDR which is a 3D Erosion (E3D) integrated with surfer or GIS tool, is a raster-based physical soil erosion model predicts the distribution of spatiotemporal erosion and also estimate the soil loss location on the watershed scale and traceable coordinates for field checking $[10,11]$. 
General physical and chemical properties of soil in the watershed to measure soil erodobility have been reported by $[1,12]$. In 2011 , the average soil loss for the Sumani watershed was $76.70 \mathrm{Mg} / \mathrm{ha} / \mathrm{y}$ where the criteria were high and exceeded the erosion of Indonesian tolerance of $17-25 \mathrm{Mg} / \mathrm{ha} / \mathrm{y}$. In detail, the distribution of erosion in Sumani watershed is as much as $51 \%$ in severe to moderate criteria found common in upland areas and $49 \%$ in low criteria found in lowland and flat areas. At other sites, it was found that the eroded soil from the high plains was predominantly deposited in the lowlands [8]. However, heavy metals have not been analyzed. We are focused on the distribution of Cadmium (Cd) in the watershed.

Modernization of agriculture and industrial expansion can, unless properly handled, cause environmental pollution. Before this occurs, environmental baseline studies must be enforced [11]. Heavy metals including $\mathrm{Cd}$ are one of the most persistent sources of environmental pollutants found in water bodies and biota, but the appearance of cadmium $(\mathrm{Cd})$ in sediments arises from natural sources of weathering of soil and anthropogenic materials from agricultural and industrial waste[13]. Heavy metals can be found everywhere in the aquatic environment [14]. Some of these heavy metal contaminants are important because of their potential toxicity properties [15] and potential adverse effects on human health if the heavy metals have reached dangerous levels as toxic pollutants. [16] Furthermore, [17] Heavy metals such as Cadmium (Cd) show more extreme toxicity, even at low levels.

Increased concentration of $\mathrm{Cd}$ in the environment intentionally or unintentionally by human actions occurs as a result of anthropogenic activities such as mining, milling or smelting of iron, application of agricultural fertilizers, and fuel combustion. The emission of this activity will be harmful to the environment and humans [18-19]. Heavy metals including Cd can also be enriched by natural processes, such as redistribution and trace element mobilization from rock or regolith weathering by surface and subsurface water, by flood, and by the processes of physical and chemical reactions occurring in the soil [20-21].

The excessive accumulation of heavy metals $(\mathrm{Cd})$ in agricultural land through irrigation and wastewater not only leads to contamination of farmland, but also affects the quality and safety of food produced in the soil when consumed by human. [22].

The Sumani watershed in West Sumatra, Indonesia, is a prime example of a setting where the use of such water constitutes a potential threat for agricultural ecosystems and human health. Sources of Cadmium (Cd) in the Sumani watershed include irrigation water, volcanic ash, and residues of fertilizers and pesticides, its use has increased since the "Green Revolution" started in Indonesia in 1972[23].

Soil texture, soil $\mathrm{pH}$, soil total carbon and geological characteristic can be a controller of the availability of cadmium in soil. Topographic factors and soil erosion can be cadmium transporters in the watershed. Detail research on the distribution of Cadmium in an agricultural watershed has not been reported to date.
This study characterizes the distribution of heavy metals especially Cadmium (Cd) in soil and in river sediment in the watershed in relation to topography and soil erosion status.

\section{Materials and methods}

\subsection{Study area}

Sumani Watershed, covering 58,330 ha, is located in Solok district (latitude $00^{\circ} 36^{\prime} 08^{\prime \prime}$ to $10^{\circ} 44^{\prime} 08^{\prime \prime} \mathrm{S}$, longitude $100^{\circ} 24^{\prime} 11^{\prime \prime}-101^{\circ} 15^{\prime} 48^{\prime \prime}$ E) on elevation of $300 \mathrm{~m}$ and 2,500 $\mathrm{m}$ above sea level and about $50 \mathrm{~km}$ east of the Padang city (Fig 1). The outlet from the watershed is Singkarak Lake. Sumani watershed which is located in a tropical zone has a very humid climate. Sumani watershed (SW) consists of five subwatershed, Lembang (S1), Sumani (S2), Aripan (S3), Gawan (S4) and Imang (S5) subwatershed. All rivers in this watershed, flow from the highlands to the lowlands and empties into Lake Singkarak (Fig 1). In the highlands is Mount Talang as an active type-A volcano that on 12 April 2005 erupted and removed volcanic ash, as a result, volcanic ash has covered the soils around Mount Talang as thick as $5 \mathrm{~cm}$. The residual effect still result from eruption going on for years [24].

Sumani watershed soil is influenced by Mount Talang Volcanic Ash. Oxic hapuldant and andic humitropept which is distributed in the Upland area of $\mathrm{S} 1$ and S2. Typic Kandiudult is derived from colluvial deposits of lava, andesite or basalt which is distributed in the lowland and Upland from S3 and middle position of S1. Aeric Tropaquept derived from river alluvium and colluvial deposits of lava which is distributed in lowland S2, S1, S3, S4, and S5. Typic Distropept is a colluvial deposit derived from the lava that is distributed in S5, S4, and S2. Typic eutropept is derived from colluvial deposits of lava are distributed only in S3. The different geologic and soil families will affect the $\mathrm{Cd}$ in agricultural soils $[8,23]$.

\subsection{Soil, river sediment sampling, and analysis}

The Study was conducted using ground surveys at 146 sites based on the type of land use, soil type and topographic position (Fig 1). Soil samples were taken at a depth of $0-20 \mathrm{~cm}$ with an assumption that the heavy metal accumulation (Cd) was available and easily taken by plant roots in this depth. We have also taken 23 river sediments that spread from upland to the lowland (Fig 1). A sample of fertilizer from $\mathrm{KCl}$, urea, and SP-36 as a representative of the agricultural fertilizers commonly used by farmers in watersheds and volcanic ash sample were taken, and $\mathrm{t}$ analyzed for content of $\mathrm{Cd}$.

Soil and river sediment samples were dried and sieved with $2 \mathrm{~mm}$ mesh size for physical-chemical analysis. Extractable heavy metal (Cd) was determined by first extracting with $0.1 \mathrm{~mol} / \mathrm{L} \mathrm{HCl}$. Extractable trace element was determined using Inductively Coupled PlasmaAtomic Emission Spectroscopy (Shimadzu ICPS 2000, 
Kyoto, Japan) in the Soil and Ecological Laboratory, Shimane University.

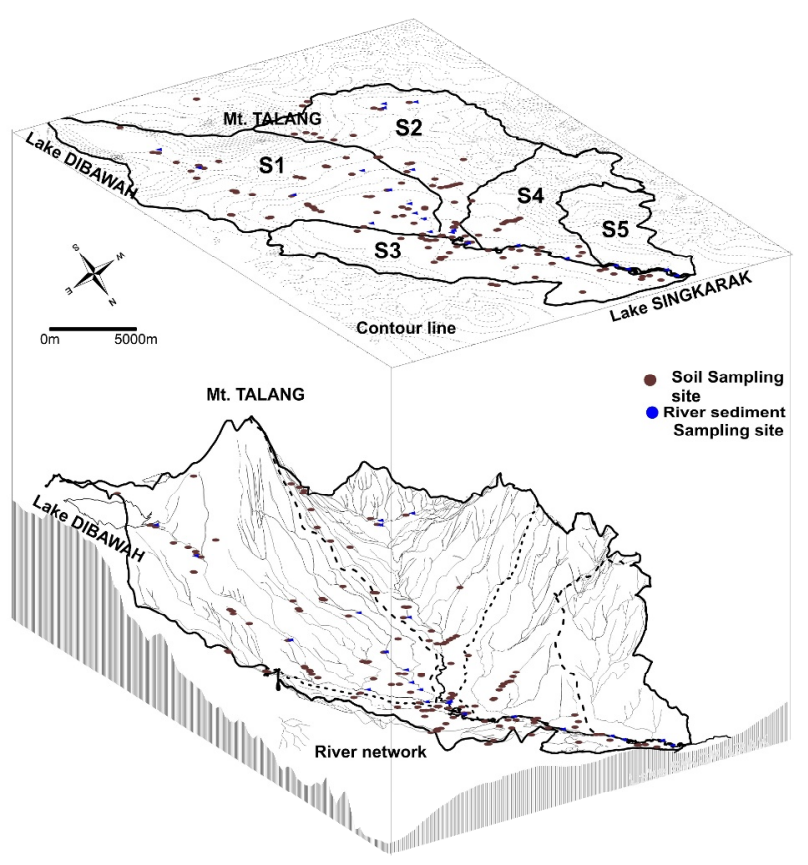

Fig. 1 Location of research in the form of 3-dimensional map (3D map) that explains the sampling of soil samples (red circle) and river sediments (blue circle) in Sumani watershed, West Sumatera

Soil $\mathrm{pH}$ was measured using the glass electrode method with a soil : water ratio of 1:2.5 [25]. Soil samples were analyzed for total carbon (TC) contents. Finely ground soil samples were oven dried at $80^{\circ} \mathrm{C}$ for approximately $24 \mathrm{~h}$. Total carbon was determined by the dry combustion method (Nelson et al. 1982) using a Yanaco CN Corder Model MT-700 (Yanagimoto MFG. Co., Kyoto, Japan). Soil texture was measured by pipette methods [26]. Heavy metals, Cadmium (Cd) in river sediment and fertilizer were analyzed by a method similar to the analysis of $(\mathrm{Cd})$ in soil. We collect land use maps, soil maps, and topographic maps to support this research. Estimates of Soil erosion has been calculated by the USLE model in previous studies[8] and for Mapping soil erosion and Cadmium in 3D map were conducted in Surfer ${ }^{\circledR} 9$ [27] dealing with data from factors soil surveys, topographic maps and geology map

\subsection{USLE model}

Soil erosion is calculated using Universal Soil Loss Equation (USLE)[7]. Six erosion factors are needed to measure annual soil losses on a watershed scale:

$$
E=R \times K x L \times S \times C \times P
$$

Where: $A$ is the estimated soil loss in $\mathrm{Mg} / \mathrm{ha} / \mathrm{y} ; R$ is Rainfall erosivity factor (dimensionless); $K$ is inherent soil erodibility (dimensionless); $L$ is length of the slope factor (dimensionless); $S$ is slope factor (dimensionless); $C$ is crop cover factor(dimensionless); and $P$ is a factor that accounts for the effects of soil conservation practices(dimensionless).
In order for the USLE model to successfully measure soil erosion of the watershed scale, the most important factor is the basic evaluation of rainfall Erosivity $(R)$ and soil Erodibility $(K)$ factor [28,33].

The initial step in making 3 dimensional map of erosion and distribution of $\mathrm{Cd}$ after laboratory analysis is dividing watershed into 39312 grid measuring $125 \mathrm{mx}$ $125 \mathrm{~m}$. Base data is then allocated and estimated in each grid coordinate and filled base data. Data were obtained by reading maps, assessing Landsat images for type and height of land use, and for mapping the use of the kriging method [27]. Quantitative distribution of soil erosion and the distribution of $\mathrm{Cd}$ are mapped with the help of Surfer ${ }^{\circledR} 9$.

\section{Results and discussion}

\subsection{General cadmium concentration and other soil properties}

Table 1. showed that the concentration of Cadmium in Sumani watershed is below the limit of toxicity based on FAO standard of 2003.[29-30].

Table 1. Mean $0.1 \mathrm{M} \mathrm{HCl}$ extractable Cadmium concentration and other general soil properties

\begin{tabular}{|c|c|c|c|}
\hline \multirow[t]{2}{*}{ Location } & \multirow{2}{*}{$\begin{array}{c}\text { Cad- } \\
\text { mium } \\
(\mathrm{Cd}) \\
(\mathbf{m g} / \mathbf{k g})\end{array}$} & \multicolumn{2}{|c|}{ Soils } \\
\hline & & pH & $\begin{array}{c}\text { TC } \\
(\mathrm{g} / \mathrm{kg})\end{array}$ \\
\hline Sumani-W $(\mathrm{n}=146)$ & 0.15 & 5.5 & 34.6 \\
\hline Maximum & 0.8 & - & - \\
\hline River Sedimen-W $(n=23)$ & 0.19 & - & - \\
\hline $\begin{array}{l}\text { Non contaminated soil In } \\
\text { Japan* }\end{array}$ & 0.3 & 5.5 & 64.3 \\
\hline Contaminated soil In Japan* & 6.1 & 5.0 & 34.8 \\
\hline Toxicity level of FAO** & 0.4 & 5.5 & - \\
\hline
\end{tabular}

Table 1. Continued

\begin{tabular}{|c|c|c|c|}
\hline \multirow[t]{2}{*}{ Location } & \multicolumn{3}{|c|}{ Soils } \\
\hline & $\begin{array}{c}\text { Sand } \\
(\%)\end{array}$ & $\begin{array}{l}\text { Silt } \\
(\%)\end{array}$ & $\begin{array}{l}\text { Clay } \\
(\%)\end{array}$ \\
\hline \multirow[t]{2}{*}{ Sumani-W $(\mathrm{n}=146)$} & 12.7 & 57.4 & 29.9 \\
\hline & \multicolumn{3}{|c|}{ Silty clay loam } \\
\hline Maximum & \multicolumn{3}{|c|}{ Silty clay loam } \\
\hline River Sedimen-W $(\mathrm{n}=23)$ & \multicolumn{3}{|c|}{ Sand - Silty clay loam } \\
\hline Non contaminated soil In Japan* & \multicolumn{3}{|c|}{ Sandy loam } \\
\hline Contaminated soil In Japan* & \multicolumn{3}{|c|}{ Sandy loam } \\
\hline Toxicity level of FAO** & \multicolumn{3}{|c|}{-} \\
\hline \multicolumn{4}{|c|}{$\begin{array}{l}\text { W=watershed; **FAO (2003) extracted by } \mathrm{HCl} ; \text { * extracted by } \\
0.1 \mathrm{M} \mathrm{HCl} \text { (Kashem et al. 2007); Non contaminated soil ir } \\
\text { Takizawa, Rokuhara, Hochirogata, Isawa (rice and vegetabl } \\
\text { soils); Contaminated soil at Miyagi, Akita, Gunma (Rice and } \\
\text { vegetables) }\end{array}$} \\
\hline
\end{tabular}

The concentrations of $\mathrm{Cd}$ in soil in Sumani watershed is proportional to the concentration of Cadmium in soil in non contaminated soil in Japan, based on data from [31] using the same extraction of 0.1 
$\mathrm{M} \mathrm{HCl}$, with a soil $\mathrm{pH}$ of 5.5 but differs in total carbon (TC) content and soil texture.

Table 1 and Table 3 showed that only three (3) of the 146 soil sample locations and one (1) of the 23 river sediment sample containing $\mathrm{Cd}$ level exceeding the toxicity level set by the FAO in 2003 (Cd 0.4 ppm). Additionally, mean concentration of $\mathrm{Cd}$ in river sediment does not exceed the limits of toxicity by FAO in 2003. Nevertheless, there is a slightly higher Cd concentrations in the sediment compared with the mean concentration of $\mathrm{Cd}$ in the soil. This indicates that there has been an accumulation of $\mathrm{Cd}$ in river sediment via translocation of material by soil erosion. According to [31] the Cd were naturally present in soil because of weathering of soil parent material. [23] and [24] reported that the parent material of Sumani watershed is dominated by volcanic ash which has a silty clay loam soil texture and containing trace elements and heavy metal. [34] Cadmium in the soil is believed to be difficult to remove the cadmium accumulates and is deposited on the soil in various chemical forms [34] reported that dissolved nutrients are assumed to be transported by surface runoff and by erosion, whereas particulate nutrients are associated with displacement of soil erosion, sediment transport flow, sediment deposition processes and erosion of the surface layer.

Table 2. Extractable Cadmium of different soil depth and Land use type in Sumani watershed

\begin{tabular}{|c|c|c|c|}
\hline \multirow{3}{*}{$\begin{array}{l}\text { Land } \\
\text { use }\end{array}$} & \multicolumn{3}{|c|}{ Cadmium (Cd) (mg/kg) } \\
\hline & \multicolumn{3}{|c|}{ Soil Depth (cm) } \\
\hline & $0-20 \mathrm{~cm}$ & $20-40 \mathrm{~cm}$ & $40-60 \mathrm{~cm}$ \\
\hline SW & $0.12-0.40$ & $0.11-0.29$ & $0.15-0.23$ \\
\hline MG & $0.06-0.20$ & $0.06-0.26$ & na \\
\hline $\mathrm{T}$ & $0.21-0.23$ & $0.15-0.17$ & na \\
\hline $\mathrm{Cm}$ & $0.00-0.23$ & $0.00-0.21$ & na \\
\hline $\mathrm{F}$ & $0.07-0.22$ & $0.07-0.19$ & na \\
\hline B & $0.09-0.27$ & $0.08-0.22$ & na \\
\hline A & $0.00-0.06$ & $0.00-0.07$ & na \\
\hline $\mathrm{S}$ & $0.06-0.24$ & $0.00-0.10$ & na \\
\hline $\mathrm{Vg}$ & $0.33-0.40$ & na & na \\
\hline $\mathrm{Rb}$ & $0.04-0.05$ & na & na \\
\hline
\end{tabular}

$\mathrm{SW}=$ rice $\quad$ production $; \mathrm{MG}=$ mixed garden; $\mathrm{T}=$ tea; $\mathrm{Cm}=$ cinnamon; $\quad \mathrm{F}=$ forest; $\quad \mathrm{B}=$ bush; $\quad \mathrm{A}=$ alang-alang; $\mathrm{S}=$ settlement; $\mathrm{Vg}=$ vegetables; $\mathrm{Rb}=$ Rubber not analyzed

Table 2 showed that there are soil samples in rice production and vegetable containing $\mathrm{Cd}$ level exceeding the toxicity level set by the FAO in 2003 (Cd 0.4 ppm). The other land use were low level i.e half of toxicity level recommended by FAO (Table 4).

\subsection{Three-dimension (3D) map of soil erosion in Sumani watershed}

Soil erosion in 3D map is shown in Fig 2, where purple and red colors indicate the areas with the highest soil erosion. Mean soil erosion is $76.68 \mathrm{Mg} / \mathrm{ha} / \mathrm{y}$ (Table 3). Soil erosion in hilly areas near mount Talang is 100-200 $\mathrm{Mg} / \mathrm{ha} / \mathrm{y}$ (upland of S1 and S2) and in the hilly area on the west side of Sumani watershed is $>200 \mathrm{Mg} / \mathrm{ha} / \mathrm{y}$ (upper position of S3, S4, and S5). The lowland part is dominated by soil erosion lower than $14 \mathrm{Mg} / \mathrm{ha} / \mathrm{y}$ (the lower the position of S1, S2, S3, S4, and S5). In addition, deposition occur in areas close to the river plains. According $[1,2,7,33]$ the area with the highest altitude is mainly sloping areas. This place has the highest soil erosion caused by the change of forest into agricultural land.

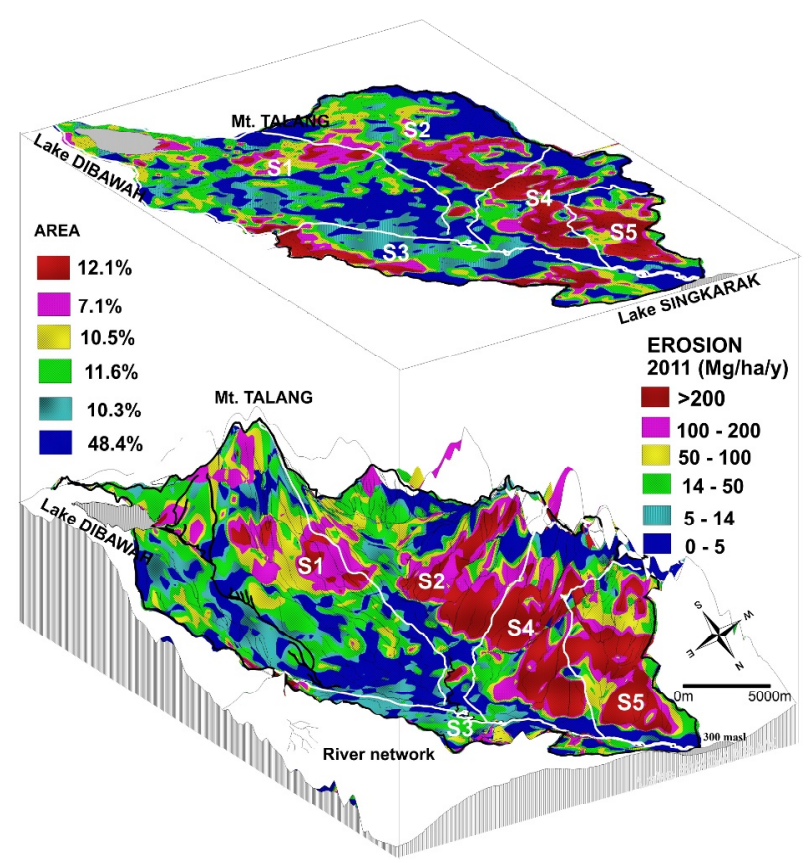

Fig. 2 Spatial distribution of estimated soil erosion in 3D map in year 2011 in Sumani watershed (S1=Lembang subwatershed ; S2=Sumani subwatershed; S3=Aripan subwatershed; S4= Gawan subwatershed; S5=Imang subwatershed), West Sumatra, Indonesia.

Table 3. Soil erosion factors in Sumani watershed

\begin{tabular}{|c|c|c|c|c|c|}
\hline $\mathbf{R}$ & $\mathbf{K}$ & LS & C & P & $\begin{array}{c}\text { Mean } \\
\text { Erosion } \\
\mathbf{M g} / \mathbf{h a} / \mathbf{y}\end{array}$ \\
\hline \multicolumn{7}{|c|}{$\mathbf{n = 1 0 8 4 0}$ grid } \\
\hline 4005.1 & 0.183 & 1.58 & 0.24 & 0.60 & 76.68 \\
\hline
\end{tabular}

$\mathrm{R}=$ Rainfall erosivity factor $; \mathrm{K}=$ soil erodibility factor; $\mathrm{LS}=$ Slope and length factor; $\mathrm{C}=$ Crop factor; $\mathrm{P}=$ Conservation factor; $\mathrm{A}=$ Soil erosion

\subsection{Distribution of cadmium (Cd) in soil and river sediment in Sumani watershed}

The soil analyses revealed that $\mathrm{Cd}$ levels exceeded toxicity level in the surrounding of mountain Talang (upland of S1 and S3) and also slightly higher in lowland (lower position of S1, S2, S3, S4, and S5) (Fig 3). The $\mathrm{Cd}$ levels are exceeded the toxicity level in river sediment founded in upland S2 (Fig 4) due to accumulation of volcanic ash. The Geology is a basaltic andesite ash. Soil type is Andisol which indicates a high volcanic ash. Basaltic andesite has a characteristic that is derived from volcanic ash containing heavy metals including Cd. High volcanic ash accumulation affects the content of Cd in soils. [24] Reported that the basaltic andesite from volcanic ash of Mount Talang containing $\mathrm{SiO} 2(57 \%), \mathrm{TiO} 2(6700 \mathrm{mg} / \mathrm{kg}), \mathrm{MnO} 2(800 \mathrm{mg} / \mathrm{kg})$ and other trace element $(3600 \mathrm{mg} / \mathrm{kg})$. 


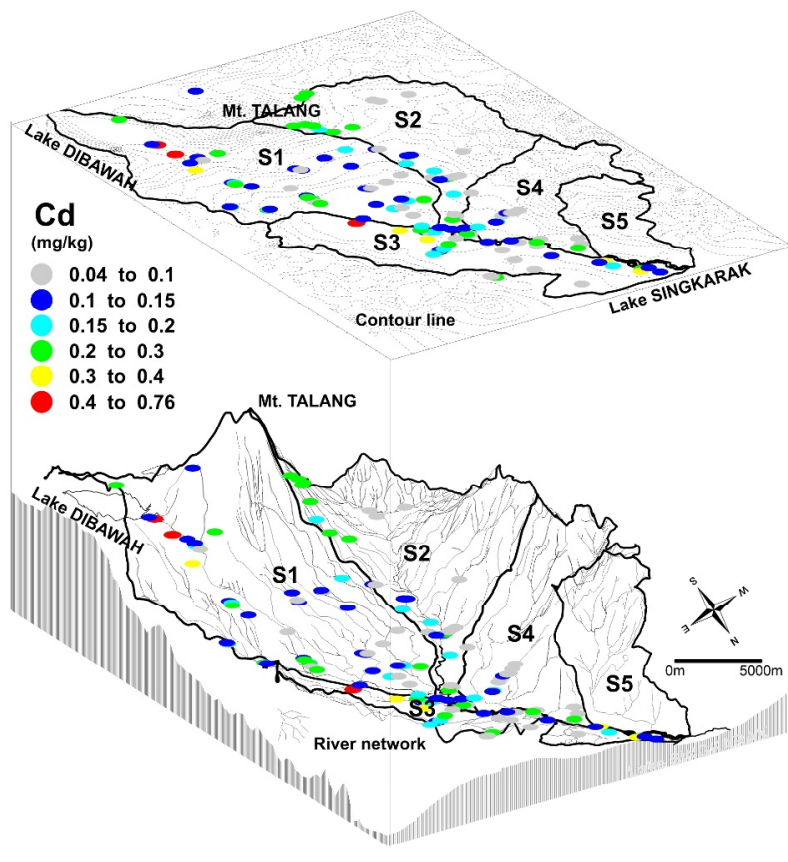

Fig. 3 The 3D map distribution of extractable $\mathrm{Cd}(0-20 \mathrm{~cm}$ soil depth) in Sumani watershed

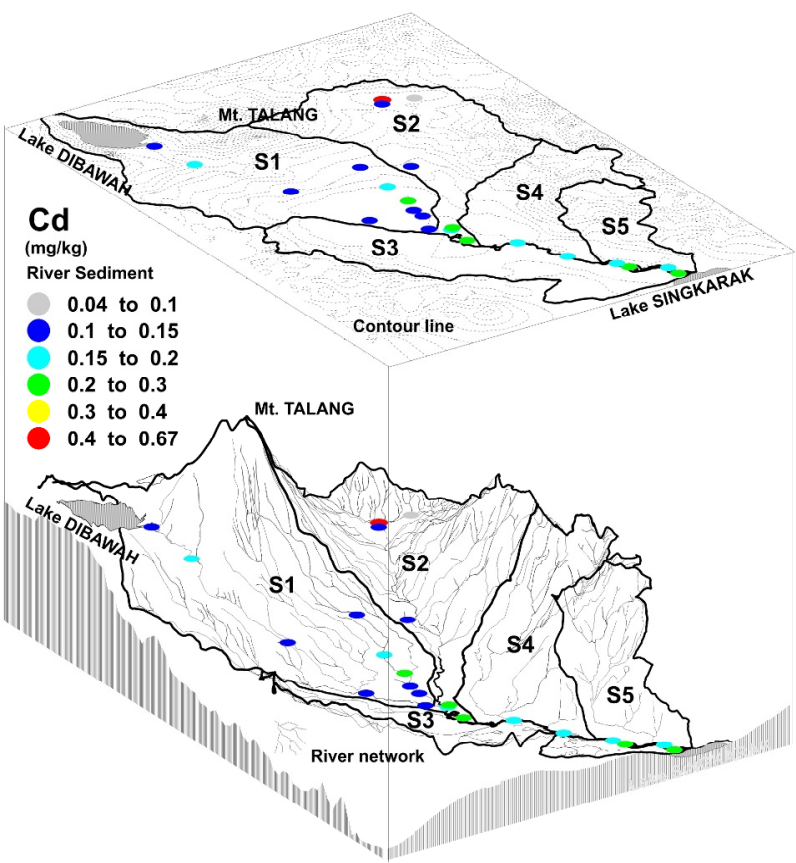

Fig. 4 The 3D map distribution of extractable $\mathrm{Cd}$ in river sediment in Sumani watershed

High soil erosion also affected $\mathrm{Cd}$. The distribution showed a negative correlation (Table 5). The $\mathrm{Cd}$ concentration was low in areas with the highest soil erosion (Fig 2, Fig 3, Fig 5). This indicates that the Cd translocation has occurred. [34] reported that the suspended nutrients including $\mathrm{Cd}$ contained in the eroded sediment from upslope erosion causing loss of nutrients in the soil. [24] reported that Mount Talang
Volcanic ash contains trace element oxides (11100 $\mathrm{mg} / \mathrm{kg}$ ) which exposed it to severe weathering by water and soluble organic acids compared with other primary minerals $[24,35,36]$.

Table 4. The number of soil sample and river sediment samples in level exceeds the toxic and non-toxic thresholds value according to FAO in 2003

\begin{tabular}{|c|c|c|c|}
\hline \multirow{2}{*}{$\begin{array}{c}\text { Extracta- } \\
\text { ble } \\
\text { Cd } \\
(\mathrm{mg} / \mathrm{kg})\end{array}$} & \multicolumn{2}{|c|}{$\begin{array}{l}\text { Soil samples } \\
(0-20 \mathrm{~cm})\end{array}$} & \multirow{2}{*}{$\begin{array}{c}\text { Toxicity } \\
\text { level } \\
\text { FAO } 2003\end{array}$} \\
\hline & $\begin{array}{c}\% \\
\text { sample }\end{array}$ & $\begin{array}{c}\mathrm{n} \\
\text { sampel }\end{array}$ & \\
\hline $0.04-0.10$ & 32.4 & 47 & below \\
\hline $0.1-0.15$ & 30.3 & 44 & below \\
\hline $0.15-0.20$ & 14.5 & 21 & below \\
\hline $0.20-0.30$ & 17.2 & 25 & below \\
\hline $0.30-0.40$ & 3.4 & 5 & below \\
\hline $0.4-0.76$ & 2.1 & 3 & toxic \\
\hline Total & 100 & 145 & \\
\hline
\end{tabular}

Table 4. Continued

\begin{tabular}{|c|c|c|c|}
\hline \multirow{2}{*}{$\begin{array}{c}\text { Extracta- } \\
\text { ble } \\
\text { Cd } \\
(\mathrm{mg} / \mathrm{kg})\end{array}$} & \multicolumn{2}{|c|}{$\begin{array}{l}\text { Rivers sediment } \\
\text { samples }\end{array}$} & \multirow{2}{*}{$\begin{array}{c}\text { Toxicity } \\
\text { level } \\
\text { FAO } 2003\end{array}$} \\
\hline & $\begin{array}{c}\% \\
\text { sample }\end{array}$ & $\begin{array}{c}\mathbf{n} \\
\text { sampel }\end{array}$ & \\
\hline $0.04-0.10$ & 4.3 & 1 & below \\
\hline $0.1-0.15$ & 39.1 & 9 & below \\
\hline $0.15-0.20$ & 30.4 & 7 & below \\
\hline $0.20-0.30$ & 21.7 & 5 & below \\
\hline $0.30-0.40$ & 0 & 0 & below \\
\hline $0.4-0.76$ & 4.3 & 1 & toxic \\
\hline Total & 100 & 23 & \\
\hline
\end{tabular}

\subsection{The cadmium (Cd) content in soil, volcanic ash, and chemical fertilizer}

The results of analysis of extractable $\mathrm{Cd}$ in volcanic ash and fertilizers commonly used by farmers in the rice production, vegetable gardens, and mix garden are presented in Table 5. Chemical fertilizers applied by farmers are $\mathrm{KCl}$, SP-36, urea fertilizer and unintended volcanic ash containing Cadmium (Cd). However, there is no significant $\mathrm{Cd}$ concentration. The doses of fertilizer used by farmers in a year are $\mathrm{KCl}(60 \mathrm{~kg} / \mathrm{ha}), \mathrm{SP}-36(200$ $\mathrm{kg} / \mathrm{ha})$ and urea $(200 \mathrm{~kg} / \mathrm{ha})$. Volcanic ash supplied significant $\mathrm{Cd}$ to the soil when Talang volcano erupted $\mathrm{Cd}$ concentration in the fertilizer was lower compared with the content of $\mathrm{Cd}$ in the soil. This shows that the concentration of Cadmium (Cd) in the fertilizers can be negligible. $\mathrm{Cd}$ in compost and other organic fertilizers was not analysed. This is based on assumption that farmers do not use much compost in the study area. [23] reported that the main source of heavy metals derived from weathering of primary minerals and volcanic ash.

\subsection{The factors and determinants of cadmium distribution}

Correlation between the concentrations of $\mathrm{Cd}$ and soil properties is presented in Table 6 . The $\mathrm{pH}$, clay, $\mathrm{R}$ factor and soil erosion showed a negative correlation with $\mathrm{Cd}$. 
Table 5. The extractable of Cadmium in chemical fertilizer and volcanic ash and possibility contamination

\begin{tabular}{|l|c|c|}
\hline Fertilizer & $\begin{array}{c}\text { 0.1 M HCl } \\
\text { extractable Cd in } \\
\text { fertilizer }\end{array}$ & $\begin{array}{c}\text { Doses } \\
\text { (kg/ha/y) }\end{array}$ \\
\hline Cd (mg/kg) & \\
\hline KCl & 0.047 & 60 \\
\hline SP-36 & 0.08 & 200 \\
\hline Urea & 8.5 & 200 \\
\hline Volcanic ash & 0.31 & 2000000 \\
\hline \multicolumn{2}{|c|}{ Contamination of Cadmium through chemical } \\
fertilization and volcanic ash \\
\hline \multicolumn{2}{|c|}{1718.82} \\
\hline Total Fertilizer & Cadmium (Cd) (mg/ha/y) \\
\hline Volcanic ash & \multicolumn{2}{|c|}{620000} \\
\hline Content of 0.1 M HCl extractable Cd in soil depth 0-20 \\
cm in 1 hectare \\
\hline Soil & Cadmium (Cd) (mg/ha) \\
\hline Total & \multicolumn{2}{|c|}{300000} \\
\hline
\end{tabular}

This implies that low $\mathrm{pH}$, clay, $\mathrm{R}$ factor, and soil erosion results in high $\mathrm{Cd}$ concentration in soil. [38] reported that concentrations of $\mathrm{Cd}$ in soil was high at $\mathrm{pH}$ 1.5 than $\mathrm{pH}$ 6.5. The silt content, $\mathrm{TC}$ and topography position show a positive correlation with $\mathrm{Cd}$. This means that the silt particles, TC, and topography could explain that the $\mathrm{Cd}$ could result from the weathering of volcanic ash. This study however did not investigate Cadmium (Cd) concentration in volcanic ash. [23] reported that soil in Sumani watershed and surrounding Mt. Talang has characteristic that can be weathered easily and contains heavy metals

Table 6. The Matrix correlation of Cadmium with soil properties, erosion factor, and topography

\begin{tabular}{|l|l|}
\hline $\mathbf{n}=\mathbf{1 4 6}$ & $\begin{array}{c}\text { Cadmium } \\
(\mathbf{C d})(\mathbf{0 - 2 0} \mathbf{~ c m})\end{array}$ \\
\hline $\mathrm{pH} \mathrm{H}_{2} \mathrm{O}$ & $-0.36^{* * *}$ \\
\hline Clay & $-0.21^{* * *}$ \\
\hline Silt & $0.19^{* *}$ \\
\hline Sand & 0.04 \\
\hline Total Carbon (TC) & $0.21^{* * *}$ \\
\hline R factor & $-0.33^{* * *}$ \\
\hline $\mathrm{K}$ factor & -0.04 \\
\hline LS factor & 0.06 \\
\hline $\mathrm{C}$ factor & -0.02 \\
\hline P factor & -0.01 \\
\hline Soil Erosion $(\mathrm{E})$ & $-0.16^{* *}$ \\
\hline Topography m.a.s.1 $(\mathrm{T})$ & $0.25^{* * *}$ \\
\hline
\end{tabular}

$* \mathrm{P}<0.1 ; * * \mathrm{P}<0.05 ; * * * \mathrm{P}<0.01 ; \mathrm{m}$. a.s.l $=$ meter above sea level

Total carbon (TC) shows a positive correlation with $\mathrm{Cd}$, indicating that $\mathrm{Cd}$ is accumulated by the $\mathrm{TC}$. In addition, soil erosion shows a negative correlation with $\mathrm{Cd}$. This means that $\mathrm{Cd}$ is found lower in sites where soil erosion is high. [35] reports that organic materials often contain and absorb trace elements and heavy metals including $\mathrm{Cd}$.

In determining the relationship between concentration of $\mathrm{Cd}$ and erosion factor, topography, correlation, and PCA were employed (Table 6 and Table
7). This clearly revealed factors determining the spatial distribution of Cd in Sumani Watershed.

Table 7. The Principle component analysis (PCA) values of the soil erosion factor, topography, and cadmium in Sumani watershed

\begin{tabular}{|l|l|l|l|}
\hline \multirow{2}{*}{ Variable } & \multicolumn{3}{|c|}{$\begin{array}{c}\text { PCA values of } \\
\text { Agricultural soil in } \\
\text { Sumani Watershed }\end{array}$} \\
\cline { 2 - 4 } & PCA1 & PCA2 & PCA3 \\
\hline Eigen values & 4.74 & 2.34 & 1.65 \\
\hline Cd & $-0,330$ & $-0,126$ & $-0,331$ \\
\hline Clay & 0,114 & 0,596 & 0,052 \\
\hline Silt & $-0,152$ & $-0,579$ & 0,030 \\
\hline Sand & $-0,031$ & 0,019 & $-0,355$ \\
\hline pH & 0,405 & 0,016 & 0,016 \\
\hline TC & $-0,365$ & 0,225 & $-0,192$ \\
\hline R factor & 0,434 & 0,012 & 0,037 \\
\hline K factor & 0,171 & $-0,152$ & $-0,057$ \\
\hline LS factor & $-0,330$ & 0,188 & 0,317 \\
\hline C factor & $-0,110$ & $-0,317$ & 0,483 \\
\hline P factor & $-0,165$ & 0,271 & 0,099 \\
\hline Soil erosion (E) & $-0,054$ & 0,085 & 0,613 \\
\hline Topography m.a.s.1 (T) & $-0,434$ & 0,055 & $-0,007$ \\
\hline
\end{tabular}

The presence of $\mathrm{Cd}$ in the same group with topography (T) and total carbon (TC) in the PCA (Table 6 and Fig 5) and strong correlation among them would suggest anthropogenic inputs (i.e., fertilizer, pesticide and organic matter from poultry waste as compost) and reflects the complex nature of organic matter [19]. While a strong relationship between $\mathrm{Cd}$ and TC may be due to a common anthropogenic source whose properties are similar to that of soil chemistry [19].

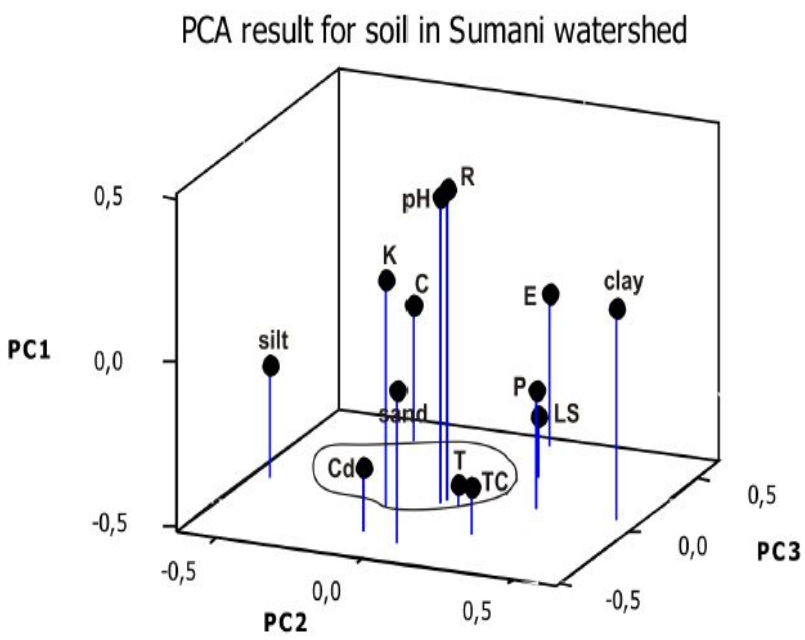

Fig. 5 Results of PCA for agricultural soil in Sumani watershed: load plots of the first three components obtained in the analysis.

The Cd in soil in the Sumani watershed show poor or negative correlation with $\mathrm{pH}$, clay, $\mathrm{R}$ factor, $\mathrm{K}$ factor, $\mathrm{C}$ factor, $\mathrm{P}$ factor and soil erosion, indicating that natural factors are at play (i.e., Rainfall, grain size, or varying parent source rock type or soil type, land use type and 
soil erosion ). The $\mathrm{Cd}$ abundances in soils are thus likely to be controlled by soil $\mathrm{pH}$, texture, topography and erosion factor that can also play an important role as a distribution of $\mathrm{Cd}$.

The enrichment of $\mathrm{Cd}$ in some soil samples (Fig 3 and Fig 4) may have arisen from atmospheric deposition and human activities, because of the adjacent intensive agriculture and near to mount Talang volcano. The $\mathrm{Cd}$ in soils might be enriched in this area by the processes of leaching, emission, runoff, erosion, and precipitation. Conversely, many samples reflect the $\mathrm{Cd}$ origin from natural weathering processes or terrestrial material, because the concentration of $\mathrm{Cd}$ is high in the soil compared to the fertilizer (Table 4). Effort should be made to overcome the contamination of $\mathrm{Cd}$ in agricultural soil because $23 \%$ of soil samples contained $\mathrm{Cd}>0.20 \mathrm{mg} / \mathrm{kg}$ (Table 4). As the number of population increase in Indonesia and used of chemical fertilizer and pesticide increase, the potential risk of contamination of $\mathrm{Cd}$ in soil will increase

\section{Conclusions}

Concentrations of Cadmium (Cd) in soil and river sediment were lower toxicity level of FAO in Sumani watershed. Distribution of $\mathrm{Cd}$ in the watershed has been affected by the following factors: Volcanic ash has affected the $\mathrm{Cd}$ in relation to Andisol characterized by high volcanic ash content and Total Carbon (TC). The $\mathrm{Cd}$ concentrations were low on the west side of watershed, which has incurred material translocation caused by high soil erosion. The low soil $\mathrm{pH}$, percentage of clay and high $\mathrm{R}$ factor and soil erosion and topography made $\mathrm{Cd}$ concentration rise in soil. The concentration of $\mathrm{Cd}$ is influenced by $\mathrm{TC}$ and the accumulation of silt on the soils. Effort should be made to reduce the contamination of $\mathrm{Cd}$ in agricultural soil. As the number of population increase in Indonesia and used of chemical fertilizer and pesticide increase, the possible risk of $\mathrm{Cd}$ contamination in soil will increase. We recommend adopting soil and water conservation practices as well as lime applications to reduce $\mathrm{Cd}$ hazard on farmland, food and humans, and to avoid soluble movement of $\mathrm{Cd}$ by erosion to the downstream.

We sincerely thank Kemenristekdikti Indonesia and LPPM Andalas University for their support in this research.

\section{References}

1. Aflizar, A. Saidi, Husnain, Ismawardi, B. Istijono, Harmailis, H. Somura, T. Wakatsuki, and T. Masunaga, Tropics. 19, 1 (2010b)

2. Aflizar, A. Saidi, Husnain, R. Indra, Darmawan, Harmailis, H. Somura, T. Wakatsuki, and T. Masunaga. Tropics. 19, 1 (2010a)

3. H. Somura, Darmawan, K. Sato, M. Ueno, Husnain, Aflizar and T. Masunaga, Pertanika. J. Trop. Agric. Sci. 39, 4 (2016)
4. A. Kusumandari, and B.R.Mitchell, Journal Soil and Water Conservation. 52, (1997)

5. World Bank, Report No. 12083-Indonesia, (Washington, DC , 1994)

6. G.K, Renard, G.R.Foster, G.A.Weesies, D.K.McCool, and D.C.. Yoder, Agric. Handb. Vol. 703 (Washington DC, 1997)

7. W.H. Wischmeier, and D.D. Smith. USDA Handbook: No. 537. (Washington, DC, 1978)

8. Aflizar, A. Roni, and T. Masunaga, J Trop Soils 18, (2013)

9. L. Hua, C.J.Moran, and P.P. Ian , Environmental Modelling \& Software 21, (2006)

10. J. Schmidt, M.V.Werner, and A .Michael, Catena 37, (1999)

11. S. Annekatarin, S .Jurgen, and T .Rolf, Catena 38, (2006)

12. Aflizar, Hak Cipta Menkumham RI no. 00311, (Dirjen KI Menkumham RI, 2016)

13. S .Suzuki, N .Djuangshi, K .Hyodo, and O .Soemarwoto, Arch. Envoron Toxicol, 9 (1980)

14. J.G. Arnason, and B.A. Fletcher, Environ Pollut 123, (2003)

15. C.M. Zvinowanda, J.O. Okonkwo, P.N. Shabalala, and N.M. Agyei, I J Environ SciTechnol 6, (2009)

16. R.H. Adams, O.F.J Guzman, and C.J. Zavala, J Environ SciTechnol 5, 4 (2008)

17. H. Yang, N.L. Rose, and R.W. Batterbee, Sci Total Environ 285, (2002)

18. R. Nicolau, C.A. Galera, and Y .Lucas, Chemos 63, 3 (2006)

19. Aflizar, Muzakkir, R. Afrizal, M.A.Rahman, J Trop Soils 21, 1 (2016)

20. Otero N, Vitoria L, Soler A, Canals A, Appl Geochem 20, (2005)

21. M.A. Muchuweti, R. Ndhlala, and A. Kasiamhuru, Food Chem 94, (2006)

22. R. D'Ascoli, M.A. Rao, P. Adamo, G. Renella, L. Landi, F.A. Rutigliano, F. Terribile, and L. Gianfreda, Environ Pollut 144, (2006)

23. Aflizar, A.I. Cornelius, E. Syafri, M.A. Rahman, Y.A. Sandjaja, and Husnain, J-SustaiN 3, 1 (2015)

24. D. Fiantis, M. Nelson, J .Shamsuddin, T.B. Goh, E. Van Ranst, Eurosian Soil Sci 43, 13 (2010)

25. IITA. Manual Series No. 5,(IITA, Ibadan, Nigeria. 1979)

26. G.W. Gee, and J.W. Bauder, American Society of Agronomy and Soil Science Society of America,( Madison, Wisconsin. 1986)

27. Golden Software. SURFER 9 for windows. (Golden, Colorado. 2010)

28. S.R. Chris, and H. Hon, Geomorphology 47, (2002)

29. FAO/WHO. Codex stand. , Rev, 1-2003, (Rome. 2003) 
30. FAO, FAO Land and Water Development Division, (Rome, 1994)

31. M.A. Kashem, B.R. Singh, T. Kondo, S. M.Imamulhuq, and S. Kawai, Int. J. Environ. Sci. Tech 4, 2 ( 2007)

32. D. Baize. INRA, (Paris, 1997)

33. Aflizar, Hak Cipta Menkumham RI no. 000100956. (Dirjen KI menkumham RI, 2018)

34. N.R. Viney, M. Sivapalan, and D .Deeley, J. Hydrol 24, (2000)

35. R.A. Dahlgren, F.C. Ugolini, W.H. Casey. Geochemica et cosmochimica. Adv 63, (1999)

36. S. Shoji, M. Narzyo, and R.A. Dahlgren, Elsevier. Amsterdam, ( the Netherlands, 1993)

37. M .Egli, G .Sartori, A .Mirabella, D. Giaccai, F. Favilli, D. Scherrer, R. Krebs, and E. Delbos, soils. Sci. Tot. Environ 408. (2010)

38. M. Frei, U. Bielert, and H. Heinrichs, Chem. Geol 170, (2000)

39. H.J. Brumsack, Geol. Rundsch 78, (1989) 